\title{
Pengaruh Perilaku Anak Remaja Kristen Di Era 4.0
}

\author{
Kariani Giawa \\ Sekolah Tinggi Agama Kristen Terpadu Pesat Salatiga \\ Email: ajakariani@,Gmail.Com
}

\begin{abstract}
Changes in adolescents are initiated by the behavior patterns and values adopted by adolescents which can be negative or positive. This can affect and result in Christian adolescents being negatively influenced, carried away and carried away in the development of the times. Teenagers cannot understand what is appropriate and pleasing to God if there is no filter of values obtained from various types of media or technology. This study uses the library method which aims to obtain better and useful research results for readers about the influence of Christian adolescent behavior in the era of 4.0. Where is the role of parents and educators in the growth and development of Christian adolescents.
\end{abstract}

Keywords: Behavior, Adolescents, Christianity, Era 4.0

\section{Abstrak}

Perubahan pada remaja diawali dari pola perilaku dan nilai-nilai yang dianut oleh remaja bisa bersifat negatif atau positif hal ini dapat mempengaruhi dan mengakibatkan remaja kristen masuk dalam pengaruh negatif, terbawa arus serta hanyut dalam perekembangan zaman. Remaja tidak dapat memahami yang sesuai dan berkenan kepada Tuhan jika tidak ada penyaring nilai yang diperoleh dari berbagai jenis media atau teknologi. Penelitian ini menggunakan metode pustaka yang bertujuan untuk mendapatkan hasil penelitian yang lebih baik dan bermanfaat untuk pembaca tentang pengaruh perilaku anak remaja Kristen di era 4.0. Dimana peran orang tua dan pendidik dalam pertumbuhan dan perkembangan remaja Kristen.

Kata kunci : Perilaku, Anak Remaja, Kristen, Era 4.0 


\section{Pendahuluan}

Masa remaja adalah pencarian jati diri dan pembentukan identitas. Yang artinya pada waktu inilah proses remaja mencari jati diri, menentukan identitas, mau mandiri dan tidak ingin bergantung dengan orangtua, sehingga diusia ini banyak remaja selalu bertentangan dengan orang tua. Perubahan pada remaja diawali dari pola perilaku dan nilai-nilai yang dianut oleh remaja bisa bersifat negatif atau positif yang membawa remaja semakin baik atau buruk seperti yang sedang marak yaitu seks bebas, ${ }^{1}$ pornografi, berpakaian tidak pantas, bergaul dengan teman yang memberi pengaruh buruk dan menggunakan narkoba, ${ }^{2}$ dimana aksi tersebut tidak sama dengan nilai dan aturan yang dianut masyarakat. $^{3}$

Sebagai seorang Kristen ingin sekali melindungi anaknya dalam pengaruh negatif yang dapat mengubah perilaku anak remaja terutama di era 4.0. Tidak akan menjadi sebuah problema jika dampaknya positif bagi diri remaja. Namun, yang menjadi masalah jika dampaknya buruk bagi masa depan remaja itu sendiri.

\footnotetext{
${ }^{1}$ Anggaunita Kiranantik, Perempuan, Anak Dan Keluaraga Dalam Arus Perubahan (Makassar, 2020).

${ }^{2}$ Gunarsa Yulia singgih, Psikologi Perkembangan Anak Dan Remaja (Jakarta, 2011).

${ }^{3}$ Anggaunita Kiranantika, Op.cit, hal. 79.
}

Hal yang berubah dari kebiasaan remaja Kristen yaitu memudarnya kebiasaan positif seperti; remaja aktif beribadah, mengikuti kegiatan di gereja, persekutuan remaja pemuda dan berbagai kegiatan lainnya yang diselenggarakan oleh gereja.

Perkembangan Zaman dan terciptanya alat teknologi yang semakin hari semakin canggih dapat mempengaruhi dan mengakibatkan remaja kristen masuk dalam pengaruh negatif, terbawa arus serta hanyut dalam perekembangan zaman. Remaja tidak dapat memahami yang sesuai dan berkenan kepada Tuhan jika tidak ada penyaring nilai yang diperoleh dari berbagai jenis media atau teknologi. ${ }^{4}$ Maka dari itu peran orang tua dan pendidik sangat penting dalam pertumbuhan dan perkembangan masa remaja. Hal ini tidak terlepas dari pola asuh orangtua yaitu memberikan kebebasan remaja untuk memilih dan jangan mengekang remaja terlalu ketat namun orang tua tetap melakukan pengawasan dan memberikan batasan sehingga ilmu dan pengetahuan yang diperoleh remaja dapat disaring atau dipilah. ${ }^{5}$

\footnotetext{
${ }^{4}$ Roswita Ndaha Julianto Simanjuntak, Bersahabat Dengan Remaja, Memahami Pergumulan Remaja Dan Bagaimana Mendampingi Mereka (Tangerang, 2014).

${ }^{5}$ Hosnan, Psikologi Perkembangan Peserta Didik (Bogor, 2016).
} 


\section{Metode Penelitian}

Metode penelitian yang diterapkan dalam jurnal ini yaitu metode kepustakaan. Menurut Sugiyono metode penelitian merupakan cara ilmiah untuk mendapatkan data yang memiliki tujuan dan makna tertentu. Dan menurut Webter's New International, penelitian adalah penelitian perlu berwaspada dan jeli dan teliti dalam mencari fakta dan prinsip-prinsip, untuk menetapkan sesuatu. ${ }^{6}$ Sedangkan penelitian merupakan alat memproses ilmu pengetahuan, dimana alat tersebut harus berjalan dengan cepat dan berkelanjutan supaya menghasilkan produk yang cukup serta berkesinambungan untuk memenuhi kebutuhan masyarakat. ${ }^{7} \quad$ Studi Pustaka adalah usaha mencermati, mengenali, dan membahas rencana penelitian secara teoritik, konseptual dan menemukan berbagai variabel penelitian dengan hubungannya, serta hasil - hasil peneletian terdahulu. $^{8}$ Dan peneliti menggunakan metode pustaka metode ini bertujuan untuk mendapatkan hasil penelitian yang lebih baik dan bermanfaat untuk pembaca.

\footnotetext{
${ }^{6}$ Sugiyono, Metode Penelitian Kuantitatif, Kualitatif, Dan R\&D ((Bandung, 2014).

${ }^{7}$ Fauzan Almanshur Djunaidi Ghony, Metodologi Penelitian Pendidikan Pendekatan Kualitatif (Malang, 2016).

${ }^{8}$ Ibid hal, 59
}

\section{Pembahasan}

Pengertian Anak Remaja

Menurut Hosman Dalam bukunya yang berjudul psikologi perkembangan peserta didik mengatakan bahwa di negaranegara barat, istilah remaja di kenal dengan "adolescence" yang diambil dari Bahasa Latin "adolescere" (kata bendanya adolescentia $=$ remaja), yang berarti tumbuh atau berkembang menjadi dewasa. ${ }^{9}$

Menurut Mappiare (1982), masa remaja berlangsung dari pertengahan usia 12 sampai dengan usia 21 tahun, bagi wanita 23 tahun dan pria 22 tahun $^{10}$.

Menurut A. Bandura mengatakan bahwa perilaku masa remaja menjadi suatu masa berlawanan karena banyak hal yang mementingkan ungkapan -ungkapan bebas dari keinginan remaja. ${ }^{11}$

Menurut E. Spranger mengukapkan pendapatnya bahwa masa remaja sangat membutuhkan pemahaman dari orang lain. ${ }^{12}$

Stanley Hall mengatakan bahwa perkembangan masa remaja merupakan masa banyak luapan emosi dan ketidak

\footnotetext{
${ }^{9}$ Hosnan, Op.cit. hal. 227

${ }^{10}$ ibid. hal. 228

${ }^{11}$ Ibid 205-206

12 Yulia Singgih Gursana, Psikologi Remaja (Jakarta, 2011).
} 
seimbangan, yang tercakup dalam " strom dan stress". 13

Berdasarkan pendapat para ahli dapat disimpulkan bahwa masa remaja adalah masa tumbuh kembang yang berlangsung dari usia 12-21 tahun, dalam masa ini remaja membutuhkan pemahaman dari orang lain dan memiliki keinginan yang berlawanan dan tidak seimbang dengan emosi remaja.

\section{Perbedaan Remaja Dulu Dan Kini/ di Era}

\section{0}

Rovolusi industri adalah masa industrialisasi meluas yang terjadi selama akhir tahun 1700-an batas penghabisan awal tahun 1800-an. Dimulai di Britania raya dan kemudian dengan cepat menyebar keseluruh dunia. Bill Gates mengatakan kalau menengok kebelakan pada ketahun 1800an, semua orang dimasa itu Miskin. Revolusi industri menobrak keadaan ini, dan banyak negara mendapat keuntungan, namun tidak berarti semua orang diuntungkan. ${ }^{14}$ Dari hal ini dapat membuka wawasan kita memahami bagai mana perkembangan yang terjadi. Dengan begitu cepat dan alat-alat semakin canggih.

\footnotetext{
13 Ibid, hal. 205

${ }^{14}$ Astrid Savitri, Mengubah Tantangan Menjadi Peluang Revolusi 4.0 (Yogyakarta, 2019).
}

Dengan perkembangan revolusi industri banyak hal alat lain yang tercipta berbasis listrik. Seperti halnya internet, telegram, telepon dan teknologi seluler lainnya. Semua ini dengan mudah mengenal dunia walau berada ditempat yang berbeda. Dengan demikian bagi anak remaja banyak hal yang akan mempengaruhi sikap perilaku. Sebab semakin hari semakin tercipta alat teknologi. Jika manusia termasuk remaja tanpa memandang agama bila tidak pandai memanajemen waktu dan mengendalikan diri menggunakan alat teknologi tersebut dapat memberikan dampak yang negatif dalam diri manusia.

Era digital merupakan masa sebagian besar manusia di dunia mengandalkan alat teknologi. Digital berasal dari Bahasa Yunani yaitu, kata Digitus yang berarti melakukan aktfitas lewat alat teknologi yang menggunakan jari jemari. Digital adalah sebuah cara yang dapat digunakan secara kompleks, dan fleksibel yang membuatnya menjadi suatu pokok dalam kehidupan manusia. Menurut wawan Setiawan Teknologi digital adalah teknologi canggih yang dapat mempermudah manusia dalam melakukan akses terhadap inormasi melalui banyak cara, serta dapat menikmati fasilitas dari teknologi digitas dengan bebas namun dampak negative juga muncul sebagai 
menancam. Memiliki arah yang sama menurut Vania Moavangi Day Era digital merupakan ciri dari era millennial, dan tidak dapat dipisahkan dengan kemampuan literasi, karena selalu berkaiatan dengan cara mendapat informasi yang sewajarnya dan yang dapat digunakan secara bijak dan beretika. $^{15}$

Dalam dunia 4.0 anak lebih senang bermain gadjet. Dalam hal ini anak-anak sudah lebih dekat dengan gadjet segala aktivitas melalui gadjet.

Dalam buku Klaus Schwab yang berjudul revolusi industri keempat, menuliskan revolusi industri keempat menciptakan sebuah dunia dimasa sistem manufaktur virtual dan fisik secara global bekerjasama satu sama lain dengan cara yang fleksibel. ${ }^{16}$ Dari pendapat ini mengajari kita dengan berada di era 4.0 memudahkan kita bisa berkomunikasi kapan saja dan dimana saja. Hal yang menjadi kesalahan ketika menyalahgunakan.

Perbedaan pertama Dulu remaja hanya hidup dengan radio dan Tv. Sekarang remaja diperhadapkan dengan $\mathrm{Tv}$ kabel,

\footnotetext{
${ }^{15}$ Fredik Melkias Boiliu, "Peran Pendidikan Agama Kristen Di Era Digital Sebagai Upaya Mengatasi Penggunaan Gadjet Yang Berlebihan Pada Anak Dalam Keluarga Di Era Disrupsi 4.0," of christian Education 1, no. 1 (2020): 25-38.

${ }^{16}$ Klaus Schwab, Revolusi Industry Keempat (Jakarta, 2019).
}

satelit, internet yang menciptakan dunia global dimana remaja masa lampau tidak mengalaminya. Pebedaan kedua mengenal kekerasan manusia. Media sejumlah besar dengan mudah memberitahu remaja pada kekerasan, apalagi remaja tertarik dan betah dengan film atau bacaan laga. Perbedaan ketiga ialah saat ini kian banyak remaja hidup dengan oran tua tunggal. ${ }^{17}$

Alat teknologi memudahkan remaja bersinggungan dengan planet tempat remaja hidup dengan demikian sebaliknya planet tempat tersebut bersingungan dengan remaja. $^{18}$

System keluarga masa kini juga mengalami perubahan makin banyak wanita karir, single parents, kawin cerai, pasangan tanpa anak, kumpulan kebo dan key yang mengangkat anak. Keluarga masa kini malahan tidak kerap kali hidup dalam keluarga batih, kebanyakan hanya bersama keluarga sendiri. Dulu remaja masih bisa mengandalkan tentangga dan keluarga besar (sepupu, tante atau nenek). saat ini mulai pudar. Dulu remaja sangat mudah membedakan hal yang bermoral dan yang tidak. Sekarang batasnya sangat sedikit. Sehingga ini menyebabkan remaja banyak

\footnotetext{
${ }^{17}$ Julianto Simanjuntak, Bersahabat Dengan Remaja, Memahami Pergumulan Remaja Dan Bagaimana Mendampingi Mereka.

${ }^{18}$ Ibid hal. 20
} 
tumbuh tanpa nilai-nilai moral, nilai kesucian dan sebagainya. Dalam hal ini dapat diketahui bahwa dulu masih banyak remaja terbatas ilmu dunia maya, sedangkan remaja masa kini secara menyeluruh memiki akses mengenal kekeberagaman kebudayaan. Segala jenis kebutuhan mereka yang menyakut hiburan, musik, mode, dan yang lainya semua dapat terpenuhi.

\section{Hal yang Mempengaruhi Perilaku Anak} Remaja Kristen di era 4.0

Hal yang secara cepat mengubah kehidupan remaja di era ini adalah perubahan zaman yang sangat cepat mengubah segala aktivitas dan kebiasaan secara radikal. Hal yang mempengaruhi salah satunya adalah pengguanaan gadget. Dalam jurnal Andri O.E. Matinahoruw mengatakan seorang yang hari hari hidupnya harus mencerminkan apa yang Yesus Kristus teladankan. $^{19}$

Menurut Stanley pengaruh remaja bersal dari lingkungan. Hal yang menggocangkan remaja sumbernya:

○ Kekecewaan dan penderitaan

\footnotetext{
${ }^{19}$ Adri O. E Matinahorum, "Peran Pemuda Kristen Ditengah Tantangan Revolusi Industri 4.0,” Ilmu Sosial Keagamaan 1, no. 1 (2020), https://ejournal.iaknambon.ac.id/index.php/N/article/ view/93/pdf .
}

○ Meningkatnya konflik, pertentangan-pertentangan dan krisis penyesuaian.

○ Impian dan khayalan

- Pacaran dan pencintaan

- Ketersaingan dari kehidupan dewasa dan norma kebudayaan. ${ }^{20}$

Rosa mengungkapkan "Aku betul-betul berusaha memberitahu orang tuaku apa yang aku rasakan, tetapi gagal-mereka malah memotong kata-kataku. Aku sudah kumpulkan keberanian untuk bicara tetapi semua berantakan" 21

Dari berbagai pengaruh yang ada dapat mempengaruhi perilaku anak maka pendidikan agama kristen mengambil peran dalam mengatasi hal ini. Pendidikan agama Kristen harusnya mengambil bagian untuk mecegah penyalahgunaa teknologi yang hdilakukan pada anak orangtua mengajarkan anak cara menggunakan gadget yang baik dan benar, dengan cara mendisplinkan anak orangtua mendampingi anak dalam penggunaan gadget dengan cara mengontrol setiap konten yang ada dikonten anakanaknya. $^{22}$

\footnotetext{
${ }^{20}$ Ibid. hal 205

${ }^{21}$ Kaum Muda, Pertanyaan Kaum Muda Jawaban Yang Praktis (Indonesia, 2015).

${ }^{22}$ Ibid. hal 25
} 
Cara Mendidik Anak Remaja Dengan Baik Diera Modern

Mendidik anak usia remaja merupakan hal yang terus dikeluhkan oleh orangtua. Tidak mudah untuk memberikan mendidik, tentu dengan ada kemajuan teknologi. Namun, dalam buku Hosnan yang berjudul Psikologi Perkembangan Peserta Didik mengungkapkan cara mendidik anak usia remaja adalah pintar-pintar memposisikan diri. Dan pendidikan agama juga salah satu mendidik anak yang baik. ${ }^{23}$ Dari hal inilah kita ketahui ketika untuk mendidik anak orangtua jangan menjadi raja. Yang harus dipatuhi perintahnya namun bagaimana orangtua bisa bijak tanpa harus memerintah. Kenapa, karna masa usia mencari jati diri saat itulah merasa paling benar. Ketika orangtua memasuki dunia dengan perintah terjadilah pemberontakan. Untuk itu hal yang harus dilakukan orangtua mendidik anak usia remaja dengan dalam buku Hosnan yang berjudul Psikologi

Perkembangan Peserta Didik menjelaskan:

- Ajarilah anak untuk mencintai serta menyayangi diri sendiri.

- Luangkan waktu Anda yang berkualitas setiap hari

${ }^{23}$ Ibid. hal 281
- Jadilah pendengar bagi anak remaja Anda yang baik.

- Seringlah tertawa, sebab kegembiraan itu menular.

○ Berilah penghargaan serta pengakuan.

- Ajarkan anak sikap disiplin dengan hormat.

- Berilah ruang bagi putra-putri Anda untuk melakukan kesalah.

○ Tanamkan nilai-nilai kejujuran, tanggungjawab, serta semangat paling membantu.

- Fokuslah perhatian Anda pada halhal yang berjalan benar.

- Tanamkanlah sikap jujur dihati anak sejak dini.

Dari pendapat ini penulis menyetujui kesepuluh penjelasan ini. Karena hal inilah yang dibutuhkan oleh remaja. ${ }^{24}$ Butuh kasih sayang, waktu bersama orangtua, sahabat bukan musuh, diakui, dan ajaran yang benar dalam berbagai aspek. Jadi, saat orangtua tidak bisa menerapkan hal ini dari itulah anak usia remaja akan menolak didikan, terjadi kebencian dan tidak mempercayai orangtua sendiri. Hal yang dibutuhkan anak remaja adalah komunikasi dan tempat untuk

\footnotetext{
${ }^{24}$ Kiranantik, Perempuan, Anak Dan Keluaraga Dalam Arus Perubahan.
} 
didengarkan juga mendapatkan kesempatan bertukar pendapat, ide dan pikiran.

\section{Kesimpulan}

Perubahan pada remaja diawali dari pola perilaku dan nilai-nilai yang dianut oleh remaja bisa bersifat negatif atau positif yang membawa remaja semakin baik atau buruk. Sebagai seorang Kristen ingin sekali melindungi anaknya dalam pengaruh negatif yang dapat mengubah perilaku anak remaja terutama di era 4.0. Peran orang tua dan pendidik sangat penting dalam pertumbuhan dan perkembangan masa remaja. Hal ini tidak terlepas dari pola asuh orangtua yaitu memberikan kebebasan pada remaja untuk memilih namun orang tua tetap melakukan pengawasan dan memberikan batasan sehingga ilmu dan pengetahuan yang diperoleh remaja dapat disaring atau dipilah.

\section{Daftar Pustaka}

Boiliu, Fredik Melkias. 'Peran Pendidikan Agama Kristen Di Era Digital Sebagai Upaya Mengatasi Penggunaan Gadjet Yang Berlebihan Pada Anak Dalam Keluarga Di Era Disrupsi 4.0.” of christian Education 1, no. 1 (2020): $25-38$.

Djunaidi Ghony, Fauzan Almanshur. Metodologi Penelitian Pendidikan
Pendekatan Kualitatif. Malang, 2016.

Gursana, Yulia Singgih. Psikologi Remaja. Jakarta, 2011.

Hosnan. Psikologi Perkembangan Peserta Didik. Bogor, 2016.

Julianto Simanjuntak, Roswita Ndaha. Bersahabat Dengan Remaja, Memahami Pergumulan Remaja Dan Bagaimana Mendampingi Mereka. Tangerang, 2014.

Kaum Muda. Pertanyaan Kaum Muda Jawaban Yang Praktis. Indonesia, 2015.

Kiranantik, Anggaunita. Perempuan, Anak Dan Keluaraga Dalam Arus Perubahan. Makassar, 2020.

Matinahorum, Adri O. E. 'Peran Pemuda Kristen Ditengah Tantangan Revolusi Industri 4.0." Ilmu Sosial Keagamaan 1, no. 1 (2020). https://ejournal.iaknambon.ac.id/index. php/N/article/view/93/pdf .

Savitri, Astrid. Mengubah Tantangan Menjadi Peluang Revolusi 4.0. Yogyakarta, 2019.

Schwab, Klaus. Revolusi Industry Keempat. Jakarta, 2019.

Sugiyono. Metode Penelitian Kuantitatif, 
Kualitatif, Dan R\&D. (Bandung, 2014.

Yulia singgih, Gunarsa. Psikologi

Perkembangan Anak Dan Remaja.

Jakarta, 2011. 